\title{
Hsiau A-Chin, Contemporary Taiwanese Cultural Nationalism
}

London, New York, Routledge, Routledge Studies in the Modern History of Asia, Vol. 7, 2000, 220 p.

\section{Edward McDonald}

\section{(2) OpenEdition}

\section{Journals}

Édition électronique

URL : http://journals.openedition.org/chinaperspectives/795

DOI : 10.4000/chinaperspectives.795

ISSN : 1996-4617

Éditeur

Centre d'étude français sur la Chine contemporaine

\section{Édition imprimée}

Date de publication : 1 février 2004

ISSN : 2070-3449

\section{Référence électronique}

Edward McDonald, "Hsiau A-Chin, Contemporary Taiwanese Cultural Nationalism », China

Perspectives [En ligne], 51 | january-february 2004, mis en ligne le 23 avril 2007, consulté le 24 septembre 2020. URL : http://journals.openedition.org/chinaperspectives/795 ; DOI : https://doi.org/ 10.4000/chinaperspectives.795

Ce document a été généré automatiquement le 24 septembre 2020

(c) All rights reserved 


\title{
Hsiau A-Chin, Contemporary Taiwanese Cultural Nationalism
}

\author{
London, New York, Routledge, Routledge Studies in the Modern History \\ of Asia, Vol. 7, 2000, 220 p.
}

\section{Edward McDonald}

1 Hsiau A-Chin's book, drawing on his doctoral dissertation research in sociology at the University of California San Diego, provides an interesting view of the rise of cultural nationalism in Taiwan in tandem with movements for its political independence, and concentrates on the "role played by such humanist intellectuals as writers, artists, historians, linguists" (p. 14). The author points out that "systematic studies of the role played by humanist intellectuals in nation building are rare" (p. 14), and as such this book represents a valuable addition to the current literature on cultural nationalism, as well as providing detailed documentation of a particular case study.

2 However, even in terms of his own aims to analyse "the Taiwanese cultural nationalism that has developed since the early 1980s" (p. 24), this work comes across as a failed attempt. This failure stems from two main sources: on the one hand, a lack of definition about the disciplinary framework and methodological basis of his analysis; on the other, a lack of co-ordination between theoretical concepts and descriptive facts. The author claims that this is a study "[d]rawing on the method of discourse analysis" in order to examine how "the concept of "Taiwanese nation" has been crafted discursively by pro-independence intellectuals" (p. 24). His analysis, however, seems to be neither sociological nor one of discourse analysis, but historical.

3 The organisation of the book as a whole shows up the study's main concerns very clearly. After an introductory chapter giving an outline of the historical, social and cultural background of Taiwan, and introducing the main theoretical concepts and descriptive areas, two relatively short chapters are devoted to discussing literary and linguistic reforms under Japanese colonial rule, and literary developments from the 1940s to the 1970s: in other words, the historical background to the main period of the 1980 s on which his study focuses. The central three chapters dealing with the 1980s and beyond, treat in turn of "Crafting a national literature", "Crafting a national language", 
and "Crafting a national history"; but the 46 pages on literature (Chapter 4, pp. 79-124), dwarf the 22 pages on language (Chapter 5, pp. 125-47), and constitute more than half as much again as the 29 pages on history (Chapter 6, pp. 148-77).

4 The main focus of this account is the development of Taiwanese literary movements and their relationship to nationalist political movements. But Dr Hsiau does not analyse the nature of the literature itself in detail, leaving his historical account in effect standing on one leg. Moreover the lack of any attempt to provide analyses of specific discourse is exacerbated by a well-nigh complete disjunction between the historical concepts and frameworks raised in his introduction, and referred to at points during the study, and his actual historical description, which thus tends to be more in the nature of a chronicle. This is all the more puzzling because it is clear that Dr Hsiau has done his homework. For example, he details some of the background work to his research as follows (p. 23):

5 From the summer of 1995 to the spring of 1996, I interviewed many pro-independence writers, literary critics, historians, activists of language movements, organizers of pirate radio stations, and leaders of college student societies. The interviews were mainly intended to facilitate my understanding of their activities and the connections among themselves, as well as to improve my grasp of their concepts of nationality.

6 Such a corpus of interviews would constitute a marvellous resource, both of ethnographic data and discursive practices, and could have been used to great effect in putting fleshing on the bones of this study's descriptive claims. In fact the only "discourse" actually cited in full is two patriotic poems written by a Taiwanese writer during the colonial period in the 1930s, and resurrected by the burgeoning Taiwanese hsiang-t'u or indigenous literary movement of the 1970s. The fact that these poems were originally written in Japanese, the common medium for many Taiwanese literati brought up under Japanese rule, and had to be translated forty years later into Mandarin, rather than the local Hoklo (Hokkien) language, for a local audience which was no longer literate in Japanese nor as yet literate in the largely unwritten Hoklo, is in itself a fascinating example of the sorts of linguistic and cultural complexities that make the case of Taiwan so interesting. However, as readers of this book, we only see the poems in an English translation, which is relegated to an endnote, a perhaps fitting sign of the lack of importance given to actual discourse analysis in this ostensibly discourse-oriented study.

7 Discourse analysis, along with ethnographic description, are two of the main analytical techniques available to academics in the social sciences and humanities, and the absence of either of these in Dr Hsiau's study leaves the reader without any real means by which to judge the accuracy of his description of the "discursive practices" which he claims to be the main focus of his work. However, even as a historical study, while Dr Hsiau is obviously well conversant with the main theoretical currents in contemporary scholarship on nationalism, by failing to closely co-ordinate theoretical frameworks with descriptive instances, his treatment misses a number of potentially useful points of comparison. For example, though referring in passing to "[s]imilar cases" of "cultural nationalisms" like those of "the Slovaks within the Hapsburg Empire, the Greeks within the Ottoman Empire, and the Irish within the British Empire" (p. 17), he does not go beyond mere mentions to explore how the concrete situations in those places resembled or differed from the Taiwanese case. For example, in Singapore, where almost $70 \%$ of the population spoke Hokkien or the mutually comprehensible 
Teochew at the beginning of the 1970s, the Speak Mandarin campaign propagated since then has in only two decades effectively cut off the younger generations of Chinese from Hokkien / Teochew in favour of Mandarin. As it is, the situation in Taiwan, which of course in itself constitutes a fascinating mix of ethnic, linguistic and ideological currents, seems to have taken place in a historical void.

There are also certain inadequacies in style that restrict the usefulness of Dr Hsiau's book. Some renderings of Chinese terms, while perfectly defensible on their own terms, are perhaps less familiar to English readers who may find them confusing: for example, "Hoklo" rather than "Hokkien" referring to the majority Taiwanese ethnicity and language. It might have been useful to retain the term "Hokkien" for overseas Chinese from Fujian province, for example in Singapore or Malaysia, while reserving "Hoklo" for their Taiwanese co-ethnics. Furthermore, while it may seem invidious to mention it, a thorough editing for idiomatic English would also have increased the accessibility of the work, and thus the strength of its arguments.

9 The facts and issues treated in this book are significant and important ones, but their treatment is, on the whole, and regrettably, an opportunity missed. 